\title{
Effects of feeding different roughage-based diets on gastric mucosa after weaning in warmblood foals
}

\author{
Alexandra Fedtke', Matthias Pfaff², Jan Volquardsen³, Monica Venner ${ }^{7}$ and Ingrid Vervuert ${ }^{4}$ \\ 1 Equine Clinic, Destedt, Germany \\ 2 Equine Clinic Ankum, Germany \\ ${ }^{3}$ Equine Clinic Börnsen, Germany \\ ${ }^{4}$ Institute of Animal Nutrition, Nutrition Diseases and Dietetics, Faculty of Veterinary Medicine, University of Leipzig, Germany
}

\begin{abstract}
Summary: Equine gastric mucosal ulcer syndrome (EGUS) is a well-known disease entity in equine medicine. Many studies have evaluated this disorder, by investigating prevalence, etiology and treatment. The effect of feeding different roughage-based diets to weanling foals has not been examined to date. In this study, 89 weanlings aged between 172-174 days were randomly allocated to two feeding trials. Trial 1 consisted of three groups: Group 1 alfalfa chaff (group 1), hay (Group 2) and Group 3: a total mixed ration (TMR). There were 20 foals in each group. Trial 2 consisted of two groups: Group 4: molassed alfalfa chaff and Group 5: hay. There were 19 foals in each group. Gastroscopic examination was performed immediately before weaning and after a feeding period of $15-16$ days. In the first part of the study (or trial 1) the prevalence of gastric mucosal lesion was $44 \%$ with a low severity score (median 0; $25 / 75 \%$ percentile: $0 / 0$ ) before weaning. There was a significant increase in the number of lesions in the Pars nonglandularis of the Curvatura minor in all groups of trial 1 post weaning. The group 1 (alfalfa chaff) exhibited significantly more mucosal lesions at the pylorus compared to group 2 (hay) and 3 (TMR). Significant healing of gastric ulcers was seen in the hay and TMR group. Results of the second part of the study (trial 2) indicated a prevalence of $86 \%$ before weaning increasing to $97 \%$ after the feeding period. There was an increase in the number of lesions at the Curvatura major and minor of both Pars nonglandularis and Pars glandularis in both groups (hay and alfalfa chaff). A significantly higher number of lesions at the pylorus were seen in the molassed alfalfa chaff group only. Despite the high number and severity score of the lesions none of the weanlings showed clinical signs associated with a gastric disorder.
\end{abstract}

Keywords: EGUS / feeding / alfalfa chaff / weaning / foal / nutrition

Citation: Fedtke A., Pfaff M., Volquardsen J., Venner M., Vervuert I. (2015) Effects of feeding different roughage-based diets on gastric mucosa after weaning in warmblood foals. Pferdeheilkunde 31, 596-602

Correspondence: PD Dr. Ingrid Vervuert, University of Leipzig, An den Tierkliniken 9, 04103 Leipzig, Germany, E-Mail: ingrid.vervuert@ vetmed.uni-leipzig.de

\section{Introduction}

Gastric mucosal ulcers are a common disease entity in race, sport and leisure horses as well as in weanlings. The combination of clinical signs like colic, slow eating, poor body condition, bruxism or depressed behavior and gastric mucosal lesions found at gastroscopy are summarized as equine gastric mucosal ulcer syndrome (EGUS) (Schusser et al. 2006, May et al. 2012). A prevalence of $78 \%$ was detected in Thoroughbred horses in training, showing no clinical signs. However, horses showing clinical signs had up to $100 \%$ gastric mucosal ulcers (Murray et al. 1989). Andrews et al. (1999) found a prevalence of EGUS in foals between 30 and $50 \%$ showing clinical signs of gastrointestinal discomfort. Dahlkamp et al. (2012) obtained similar results of prevalence but in clinically normal weanlings.

The following factors are implicated in the development of superficial or ulcerative gastric mucosal lesions: nonsteroidal anti-inflammatory drugs, diets containing high amounts of grain, strenuous exercise and stress due to transport or starvation periods of $24 \mathrm{~h}$ as well as stall confinement (Murray 1994, Murray and Eichorn 1996, Andrews et al. 1999, Murray and Grady 2002). Horses have a continuous gastric acid secretion of 1.5 I containing 40 to $60 \mathrm{mmol}$ hydrochloric acid $(\mathrm{HCL}$ ) per hour (Picavet 2002) but buffering saliva production starts only with feed intake (Alexander 1966). Due to the lack of a protective mucus layer, the non-glandular portion is vul- nerable to a prolonged exposure to $\mathrm{HCL}$. The membrane potential of the Pars nonglandularis cells decreases which results in an impairment of the sodium transport system. Consequently an osmotic influx of water into the cells leads to swelling and degradation (Carney et al. 1981, Argenzio et al. 1999). Furthermore, periods of starvation result in an increased concentration of bile acids through gastroduodenal reflux. Within this acid milieu in the stomach, bile acids are not dissociated and due to their lipophilic property they penetrate the gastric mucosa and damage ion transport systems of the epithelium (Argenzio 1999). As a consequence the mucosa becomes more permeable for hydrogen ions (Bernschneider et al. 1999). In addition, short chain fatty acids (SCFA) such as butyrate, acetate and propionic acid are produced by bacterial fermentation after the intake of high starch diets. SCFA act in a synergistic way with hydrochloric acid (HCL) by producing mucosal injuries as well as by interacting with the sodium transport system and therefore weaken the mucosal barrier (Nadeau et al. 2003).

Besides optimizing feeding and housing management, the treatment with pharmaceutical drugs such as omeprazole reduces gastric acid production, resulting in gastric $\mathrm{pH}$ values above 4 (Birkmann et al. 2014). Other drugs like sucralfate improve the prostaglandin E (PGE) synthesis, by stimulating the bicarbonate and mucus secretion and impeding hydrochloric acid release (Bell et al. 2007). With regard to feeding practices, a high forage intake and a low starch intake are 
strongly recommended. For example, hay or grass intake during 12 to 16 hours per day may improve gastric mucosa health as constant saliva flow will buffer gastric $\mathrm{pH}$ up to 4 as reviewed by Vervuert and Coenen (2002). In order to offset the problems associated with the rapid consumption and episodic feeding of concentrate it is common practice to recommend that chopped roughage be mixed with the concentrate or, that roughage (grass meal or hay) be fed before the concentrate. In several studies a protective effect of feeding alfalfa hay to horses has been reported. The beneficial effect of feeding alfalfa hay appeared to be related to an increase in gastric $\mathrm{pH}$ above 4 . This is due to the buffering properties of calcium and protein as well as the higher production of acetate, propionate and isovaleriate in the stomach content (Haaland et al. 1982, Nadeau et al. 2000, Lybbert 2007).

The aim of the present study was to investigate the effects of feeding alfalfa chaff on gastric mucosa in weanlings. We hypothesized that feeding a high proportion of alfalfa chaff would improve gastric mucosa in foals similarly to the results obtained in adult horses when fed with alfalfa hay.

\section{Materials and Methods}

\section{Study design}

89 warmblood weanlings were included in a blinded control study consisting of two consecutive feed trials. The first trial (October to November 2011 ) consisted of three groups, with 20 weanlings in each group. The second trial (November to December 2011 ) consisted of two groups with 19 weanlings in each group. In both trials a gastroscopic examination was performed before weaning and again after the feeding period of 15-16 days.

\section{Animals}

On one horse breeding farm, 89 warmblood foals $(41$ females, 48 males) were included in this study. All foals were born there and kept in the same environment until after weaning. In Trial 1, foals were aged $174 \pm 4.75$ days (alfalfa group), $172 \pm 5.99$ days (TMR group) and $173 \pm 4.65$ days (hay group) at weaning and in the second trial between $181 \pm 7.93$ (molassed alfalfa group) and $186 \pm 9.25$ (hay group) days without any significant differences in the age of the foals between groups and trials. One week prior to the study, the foals were maintained in groups of 10 to 30 mares and foals in barns $\left(27 \times 9 \mathrm{~m}^{2}\right)$ with free access to a paddock $\left(17 \times 9 \mathrm{~m}^{2}\right)$. In the barns, the animals were bedded on straw. Weaning was performed on the same day for all foals of each trial respectively. Mares and foals were separated from each other and housed in different locations on the stud farm. Before and after the weaning procedure the foals remained within the same barns until the study was finished.

\section{Feeding}

Prior to the start of the trials, each mare and foal received a daily total mixed ration (TMR) of $\sim 9 \mathrm{~kg}$ (as fed) offered in long feeding trough hereby providing one feeding place per mare and foal. Hay was provided ad libitum in hayracks. The TMR was divided into a morning and evening feed. The rations were formulated to meet or to exceed the mares' energy and nutrient requirement. The feed consisted of $3 \mathrm{~kg}$ of corn silage, $3 \mathrm{~kg}$ of grass silage, $2 \mathrm{~kg}$ of oat, $0.5 \mathrm{~kg}$ of straw, $0.3 \mathrm{~kg}$ of soybean meal, $0.05 \mathrm{~kg}$ of a commercial mineral vitamin supplement and $0.04 \mathrm{~kg}$ of $\mathrm{CaCO}^{3}$. Water was provided ad libitum. Nutrient analyses of the feedstuffs are shown in Table 2.

After weaning for both trials, the foals were randomly and blindly allocated to one of the following groups:

- Group 1: Alfalfa chaff I $(n=21)$ : alfalfa chaff (5.5 kg/weanling/day) was divided into two meals and fed in the morning and evening. $2.7 \mathrm{~kg}$ oats/weanling/day mixed with $0.05 \mathrm{~kg} /$ weanling/day mineral vitamin supplement were provided in three meals. Each $\mathrm{kg}$ of the alfalfa chaff was humidified with 0.51 of water and alfalfa chaff was mixed by hand with the oats. The particle size of the alfalfa chaff is shown in Table 1.

- Group 2: TMR (control) ( $n=16)$ : total mixed ration (TMR) twice daily $(9 \mathrm{~kg} /$ weanling/day) and hay ad libitum. The TMR consisted of $3 \mathrm{~kg}$ corn silage, $3 \mathrm{~kg}$ of grass silage, $2 \mathrm{~kg}$ of oat, $0.5 \mathrm{~kg}$ of straw, $0.3 \mathrm{~kg}$ of soybean meal, $0.05 \mathrm{~kg}$ of a commercial mineral vitamin supplement.

- Group 3: Hay I (control) ( $\mathrm{n}=16$ ): hay ad libitum and $2.7 \mathrm{~kg}$ oats/weanling/day mixed with $0.05 \mathrm{~kg} /$ weanling/day mineral vitamin supplement were provided into three meals.

The second trial consisted of two groups $(n=19$ in each group):

\begin{tabular}{|c|c|c|c|c|c|}
\hline \multicolumn{6}{|c|}{ Table 1 Percentage (\%) of different particle sizes for alfalfa chaff } \\
\hline Forage & $>4 \mathrm{~mm}$ & $>2 \mathrm{~mm}$ & $>1 \mathrm{~mm}$ & $>0.5 \mathrm{~mm}$ & $<0.5 \mathrm{~mm}$ \\
\hline Alfalfa chaff & 33.6 & 11.9 & 10.6 & 12.6 & 36.6 \\
\hline Molassed alfalfa chaff & 40.0 & 10.4 & 4.8 & 4.3 & 40.1 \\
\hline
\end{tabular}

\begin{tabular}{lcccc}
\hline Table 2 & Chemical composition of the feeds (g/kg DM) & & & \\
\hline Parameter & Hay & Alfalfa chaff & TMR & Oats \\
\hline Crude ash & 53 & 71 & 59 & 25 \\
Crude protein & 93 & 150 & 120 & 142 \\
Crude fiber & 290 & 412 & 231 & 115 \\
Crude fat & 24 & 21 & 33 & 47 \\
\hline
\end{tabular}


- Group 4: Molassed alfalfa chaff $(n=18)$ : molassed alfalfa chaff $(5.5 \mathrm{~kg} /$ weanling/ day) twice daily. $0.05 \mathrm{~kg} /$ weanling/day mineral vitamin supplement was combined with $2.7 \mathrm{~kg}$ oats/weanling/day and provided three times a day.

- Group 5: Hay II (control) $(n=18)$ : hay ad libitum as well as $2.7 \mathrm{~kg}$ oats/weanling/day mixed with $0.05 \mathrm{~kg} /$ weanling/day mineral vitamin supplement provided three times a day.

The foals in each group and in each trial were housed together in the same barns $\left(27 \times 9 \mathrm{~m}^{2}\right)$ prior to weaning until the end of the study with free access to a paddock $\left(17 \times 9 \mathrm{~m}^{2}\right)$ and bedded on straw. All weanlings had free access to water at all times and received the respective rations for 16 days. Feed intake was monitored by one trained person and any leftovers were collected and re-weighed to measure the daily feed intake. Feedstuffs were weighed using an electronic scale (MAULparcel50, Jakob Maul GmbH, Bad König, Germany) with a precision of measurements of $10 \mathrm{~g}$.

\section{Gastroscopy}

Gastroscopy was performed 3 to 4 days prior to weaning and after 15 to 16 days of the feeding period in the first trial and after 15 days in the second trial respectively. Before gastroscopic examination, milk and feed were withheld for 10 hours. Before gastroscopy all foals underwent a clinical examination. The foals were sedated with $0.02 \mathrm{mg}$ per $\mathrm{kg} \mathrm{BW}$ iv detomidinhydrochloride (Domosedan ${ }^{\circledR}$, Elanco Animal Health, Bad Homburg, Germany). A 3.25 m flexible video endoscope (Karl Storz GmbH \& Co. KG, Tuttlingen) was connected to a monitor (Gastro Pack ${ }^{\circledR}$ Karl Storz GmbH \& Co. KG, Tuttlingen) and a light source was used.

Eight separate regions of the stomach were evaluated: Saccus caecus ventriculi, Pars nonglandularis and Pars glandularis of the Curvatura major, Pars nonglandularis and Pars glandularis of the Curvatura minor, the pylorus in combination with the antrum pyloricum and the proximal part of the duodenum. Gastric mucosa was graded blindly by an experienced investigator (M.V.). The scoring system (Score 0 to 4) validated by Andrews et al. (1999) for each gastric region was used.

\section{Body weight}

An electronic weigh scale was used to measure body weight (Firma Müller, Jagstzell, Germany) before the first and second gastroscopic examination.

\section{Statistics}

Body weight (BW) was expressed as the mean \pm SD or as a percentage of BW. The stomach scores were presented as the median, 25/75\% percentile, minimum and maximum. Data analysis was performed using a statistical software program (STATISTIKA, StatSoft). Data for BW was normally distributed using Shapiro-Wilk W test. The Wilcoxon signed rank test was used to compare the differences within a group before and after weaning. Kruskal-Wallis ANOVA was performed to com- pare the different treatment groups. Statistical significance was established at $p<0.05$.

\section{Results Trial I}

Body weight

The mean body weight prior to weaning was $252 \pm 26.5 \mathrm{~kg}$ in the hay group, $252 \pm 21.9 \mathrm{~kg}$ in the TMR group and $251 \pm 19.2 \mathrm{~kg}$ in the alfalfa chaff group. At the end of the trial no significant changes in body weight were measured (hay $248 \pm 26.9 \mathrm{~kg} ; \quad$ TMR $258 \pm 21.3 \mathrm{~kg}$; alfalfa chaff $254 \pm 20.3 \mathrm{~kg}$, feeding $\mathrm{p}>0.05)$. The mean daily dry matter intake (DMI) in each weanling was $7.2 \pm 0.02 \mathrm{~kg}$ of TMR, $5.0 \pm 0.03 \mathrm{~kg}$ feeding hay I and $4.87 \pm 0.987 \mathrm{~kg}$ feeding alfalfa chaff, respectively. The DMl feeding TMR was significantly higher than feeding hay or alfalfa chaff $(p<0.05)$.

\section{Gastric lesion scores}

Before weaning, the prevalence of gastric mucosa lesions ( $\geq$ one lesion considering all locations in the stomach) was $44 \%$, but with a very low severity score (median 0, 25/75\% percentile: 0/0). None of the foals showed any clinical signs associated with gastric mucosa lesions, such as poor body condition, colic, slow eating or depression. After weaning, the prevalence of gastric mucosa lesions ( $\geq$ one lesion considering all locations in the stomach) increased significantly up to $93 \%$. Weaning and feeding did not significantly affect gastric mucosa of the Curvatura major of the Pars nonglandularis and Pars glandularis (Figure 1). Gastric mucosa lesions increased significantly in the Pars nonglandularis of the Curvatura minor from a median score of 0 (25/75 percentile: 0/0) before weaning to a median score of 2 (25/75\% percentile: 0-1/2) after weaning for feeding hay or TMR (Figure 2) or to a median score of 3 (25/75\% percentile: $2 / 4)$ for feeding alfalfa chaff I (Figure 2, weaning and feeding $p<0.05$ ). In the group of foals fed with alfalfa chaff the pylorus showed a median score of 0 (25/75 percentile: $0 / 0.5)$ before weaning and a median score of 2 (25/75\% percentile: 2/2) after weaning (weaning $p<0.05$, Figure 3). Significant lower gastric mucosa lesions around the pylorus were found in the group fed with hay (median score of 0, 25/75\% percentile: $0 / 1$, Figure 3 ) and the TMR-group (median score of 0 , 25/75\% percentile: 0/0, Figure 3) after weaning compared to the group fed with alfalfa chaff (feeding $p<0.05$ ). No gastric mucosa lesions were found in the Saccus caecus or in the proximal duodenum before and after weaning (data not shown) in the different feeding regimes.

\section{Trial 2}

Body weight

Before weaning, the mean body weight of the foals in the group fed with molassed alfalfa was $240 \pm 22.9 \mathrm{~kg}$ and at the end of the study $254 \pm 24.2 \mathrm{~kg}$. Weanlings of the hay group had a body weight of $257 \pm 25.8 \mathrm{~kg}$ before weaning and of $260 \pm 25.1 \mathrm{~kg}$ at the end of the study (treatment $\mathrm{p}>0.05$ ). The mean daily dry matter intake (DMI) in each weanling was 
$6.3 \mathrm{~kg} \pm 1.17 \mathrm{~kg}$ in the molassed alfalfa chaff group and $5.2 \pm 0.03 \mathrm{~kg}$ in the hay group respectively.

\section{Gastric lesion scores}

Before weaning, the prevalence of gastric mucosa lesions ( $\geq 0$ ne lesion considering all locations in the stomach) was $86 \%$,

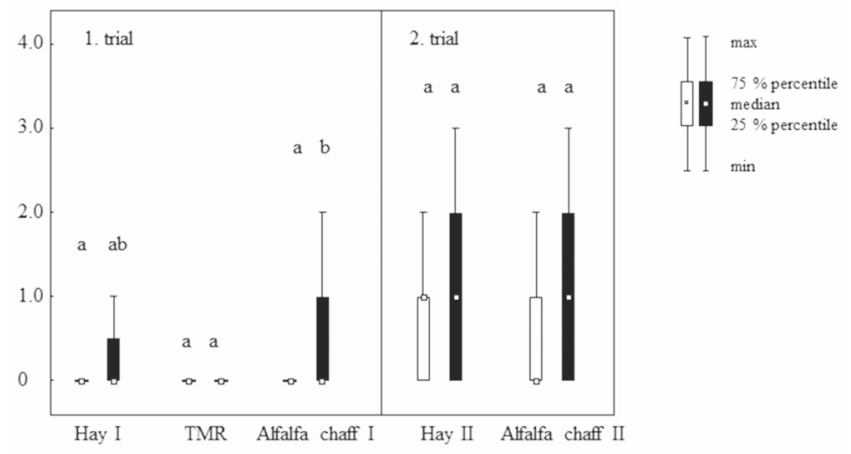

Fig. 1 EGUS score for the Curvatura major of the Pars nonglandularis and Pars glandularis before and after weaning for the different feeding groups. Data were expressed as the median, 25/75 \% percentile, minimum and maximum score. The white bars reflect EGUS score before weaning, and the black bars reflect EGUS score after weaning for the different feeding groups.

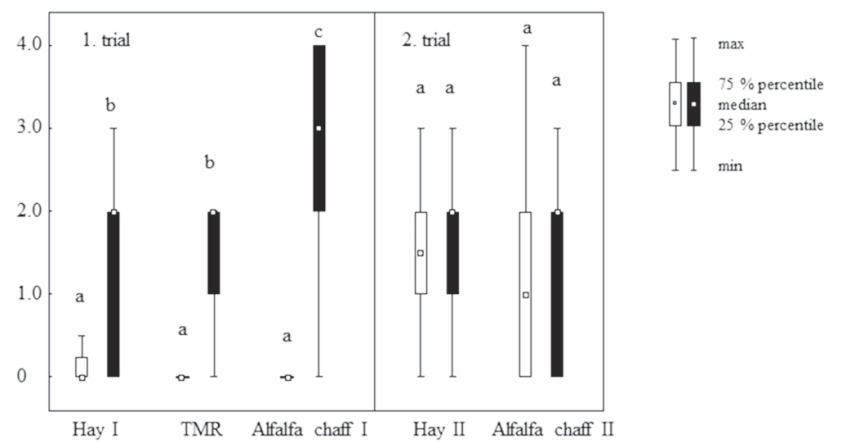

Fig. 2 EGUS score for the Curvatura minor of the Pars nonglandularis before and after weaning for the different feeding groups. Data were expressed as the median, 25/75\% percentile, minimum and maximum score. The white bars reflect EGUS score before weaning, and the black bars reflect EGUS score after weaning for the different feeding groups.

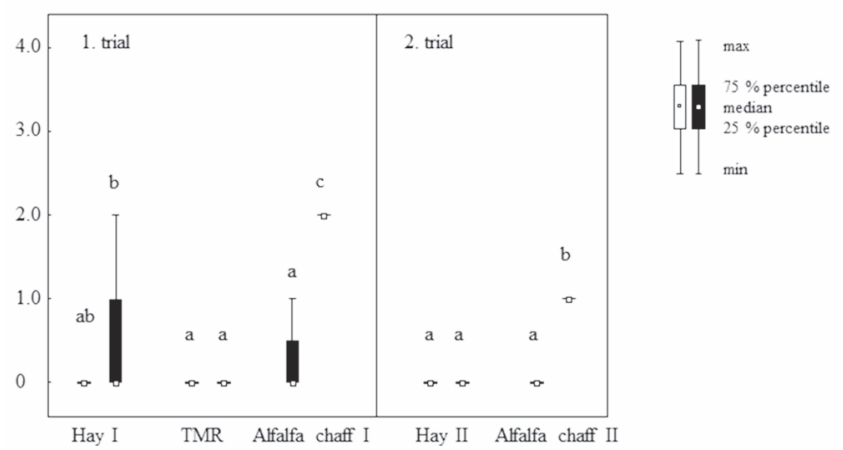

Fig. 3 EGUS score for the pylorus before and after weaning for the different feeding groups. Data were expressed as the median, $25 / 75 \%$ percentile, minimum and maximum score. The white bars reflect EGUS score before weaning, and the black bars reflect EGUS score after weaning for the different feeding groups. but with a very low severity score (median 0, 25/75 percentile: $1 / 0)$. None of the foals showed any clinical signs that are commonly related to the presence of gastric mucosa lesions, such as poor body condition, colic, slow eating or depression.

After weaning, the prevalence of gastric mucosa lesions ( $\geq 0 n e$ lesion considering all locations in the stomach) increased significantly up to $97 \%$. After weaning gastric mucosa lesions of the Curvatura major of the Pars nonglandularis and Pars glandularis increased numerically in the molassed alfalfa chaff group (median 1, 25/75\% percentile 0/2, Figure 1, $p=0.06$ ), whereas similar gastric mucosa lesions scores were recorded for hay $I I$ before (median 1, 25/75\% percentile 0/1) and after weaning (median 1, 25/75\% percentile 0/2, Figure 1). Gastric mucosal lesions increased slightly in the Pars nonglandularis of the Curvatura minor after weaning in both diet groups (Figure 2, weaning $p=0.06$ ). Feeding molassed alfalfa chaff significantly induced gastric mucosa lesions in the pylorus from a median score of 0 (25/75 percentile: $0 / 0)$ before weaning to a median score of 1 (25/75\% percentile: $1 / 1$ ) after weaning (weaning $p<0.05$ ). No pylorus findings were monitored in hay group before and after weaning (feeding $p<0.05)$. No gastric mucosa lesions were found in the Saccus caecus or in the proximal duodenum before and after weaning (data not shown) for both diets.

\section{Discussion}

In both trials there was a high prevalence of gastric mucosal lesions (first trial: 44\%, second trial: $86 \%$ ) but with a low severity score already before weaning. Gastric mucosal lesions increased significantly after weaning up to $93 \%$ or $97 \%$ in the first trial and in the second trial respectively. In earlier studies a lower prevalence of gastric mucosal lesions had been reported. Murray (1989) showed a prevalence of $9 \%$ (foals aged 3-10 months), 30\% in foals aged 70-85 days (Murray 1999) and $41-55 \%$ in foals with an age of 148-237 days (Dahlkamp et al. 2012). After weaning most gastric mucosa lesions were found in the Pars glandularis and the pylorus especially in the group fed alfalfa chaff.

In the first trial, one limitation of the study was the reduced feed intake of the alfalfa chaff during the first three days after weaning compared to hay or TMR group. In consequence the ratio between roughage and concentrate was different between the various feeding groups. Hay intake is linked to liquid gastric chyme content due to a high saliva production and the liquid chyme enters the stomach in a rapid manner (Meyer et al. 1980). In contrast dry chyme content after concentrate intake is associated with a longer retention time in the stomach (Meyer et al. 1980, Coenen 1990, Murray and Schusser 1993). A prolonged gastric emptying seemed to be related to a higher secretion of hydrochloric acid and a more intensive bacterial fermentation (Argenzio 1974, de Fombelle et al. 2003). Bacterial fermentation results in the production of short chain fatty acids (SFCA) which are able to penetrate the lipophilic mucosa resulting in cell swelling, blockage of intracellular sodium transport system and damage of these epithelial cells (Nadeau et al. 2003), especially under the conditions of a low gastric $\mathrm{pH}$. Furthermore, a decreased saliva production by a low forage intake is associated with a lowered buffering function in the stomach (review Vervuert 
and Coenen 2004). However, the weanlings of the second trial had an increased dry matter intake when fed the molassed alfalfa chaff than feeding hay, which attenuates the limitation of the first trial.

Alfalfa hey is reported to have a protective effect on gastric mucosa by buffering gastric $\mathrm{pH}$ due to its high contents of calcium, magnesium and protein. Feeding alfalfa hay combined with grain to six adult horses over a period of 14 days increased $\mathrm{pH}$ in gastric juice over 2 to 5 hours after feeding (Nadeau et al. 2000). Furthermore the number and severity of gastric mucosal lesions located in the Pars nonglandularis were significantly lower compared to horses fed bromegrass hay (Nadeau et al. 2000). It is speculated that the protective effect of alfalfa hey on the stomach mucosa is caused by the higher calcium and protein content, which may have a buffering effect (Nadeau et al. 2000). Lybbert (2007) published similar results in 24 yearlings.

In contrast to these studies a superior effect by feeding alfalfa chaff on stomach mucosa in weanlings was not observed in our study. In fact, a significantly higher lesion score in the pyloric region was detected in the alfalfa chaff and molassed alfalfa chaff groups when compared to the other feeding groups. A possible explanation for the changes at the pylorus might be the particle size of the alfalfa chaff. Studies in pigs showed that feeding diets with a small particle size are associated with esophagogastric ulcers (Mahan et al. 1966) and gastric ulcers (Mößeler et al. 2012). In pigs Mößeler et al. (2010) fed four different diets with different grinding intensities and different physical forms (pelleted against meal). Feeding a finely grinded and pelleted diet resulted in a liquid gastric chyme with similar $\mathrm{pH}$ values for the different regions of the stomach. In contrast, a coarsely ground diet caused a stratification of the gastric chyme with large $\mathrm{pH}$ differences for the different regions. However, finely ground diets were associated with more severe stomach ulcers in the Pars nonglandularis than feeding coarsely ground unpelleted diets (Mößeler et al. 2012). From the results obtained in pigs we speculate that particle size is also an important issue in gastric mucosa health in the horse, but from our study it is still not clear whether the fine or the harsh, acanthous structure of alfalfa chaff may have an impact on gastric mucosa. In an ongoing experiment, foals fed alfalfa chaff had significantly higher gastric mucosa lesions especially at the pylorus, than feeding finely grinded alfalfa pellets (Vondran et al., under revision). Therefore we assume that alfalfa chaff induced gastric mucosa lesions probably due to mechanical injury to the mucosa as the pyloric region is an area of the stomach with high motility.

\section{Acknowledgment}

The authors thank Mrs. Mariann Klay for assistance in writing the manuscript. The authors thank Fa. Storz for lending the Equine Gastroscope, enabling a high quality visualization of the gastric mucosa down to the pylorus

\section{Animal welfare statement}

The project was approved by the Ethics Committee for the Animal Rights Protection of the District Government, in accor- dance with the German legislation for animal rights and welfare $(A 07 / 10)$.

\section{References}

Alexander F. (1966) A study of parotid salivation in the horse. Physiology 184, 646-656

Andrews F., Bernard W., Byars D., Cohen N., Divers T., Mac Allister C., Mc Gladdery A., Merritt A., Murray M., Orsini J., Snyder J., Vatistas N. (1999) Recommendations for the diagnosis and treatment of equine gastric ulcer syndrome (EGUS). Equine Vet. Educ. $11,262-272$

Argenzio R. A., Southworth M., Stevens C. E. (1974) Sites of organic acid production and absorption in the equine gastrointestinal tract. Am. J. Vet. Physiol. 226,1035-1042

Argenzio R. A. (1999) Comparative pathophysiology of nonglandular ulcer disease: a review of experimental studies. Equine Vet. J. Suppl. 29, 19-23

Bell R. J. W., Mogg T. D., Kingston J. K. (2007) Equine gastric ulcer syndrome in adult horses: A review. N. Zeal. Vet. J. 55, 1-12

Bernschneider H. M., Blikslager A. T., Roberts M. C. (1999) Role of duodenal reflux in nonglandular gastric ulcer disease of the mature horse. Equine Vet. J. Suppl. 29, 24-29

Birkmann K., Junge H. K., Maischberger E. (2014) Efficacy of omeprazole powder paste or enteric-coated formulation in healing of gastric ulcers in horses. J. V. Int. Med. 28, 925-933

Carney C. N., Orlando R. C., Powell D., Dotson M. M. (1981) Morphologic alterations in early acid-induced epithelial injury of the rabbit esophagus. Lab. Invest 45, 198-208

Coenen M. (1990) Beobachtungen zum Vorkommen fütterungsbedingter Magenulzera beim Pferd. Schweiz. Arch. Tierheilk. 132, $121-126$

Dahlkamp M., Feige K., Venner M. (2012) Gastric lesions in foals before and after weanling: Influence of Omeprazole. Pferdeheilkunde 28, 561-569

De Fombelle A., Varloud M., Goacher A.-G., Jacotot E., Philippeau C., Drogoul C., Julliand V. (2003) Characterization of the microbial and biochemical profile of the different segments of the digestive tract in horses given two distinct diets. Animal science 77, 293-304

Furr M. O., Murray M. J., Ferguson D. C. (1992) The effects of stress on gastric ulceration, T3, T4, reverse T3 and Cortisol in neonatal foal. Equine Vet. J. 24, 37-40

Haaland G., Tyrrell H., Moe P., Wheeler W. (1982) Effect of crude protein level and limestone buffer in diets fed at two levels of intake on rumen $\mathrm{pH}$, ammonia-nitrogen, buffering capacity and volatile fatty acid concentration in cattle. J. Anim. Sci. 55, 943-955

Lybbert T. C. (2007) Gastric ulcer syndrome in exercising horses fed different types of hay. Texas A \& M University, Master Thesis

Mahan D. C., Pickett R. A., Perry T. W., Curtin T. M., Featherston W. R., Beeson W. M. (1966) Influence of various nutritional factors and physical form of feed on esophagogastric ulcers in swine. J. Anim. Sci. 25, 1019-1023

May A., Venner M., Cavicchiolo E., Gehlen H. (2012) Diagnostic and treatment of equine stomach diseases. Pferdeheilkunde 28, 388-405

Meyer H., Alswede L., Pferdekamp M. (1980) Untersuchungen über Magenentleerung und Zusammensetzung des Mageninhaltes beim Pferd. Dtsch. Tierärztl. Wschr. 87, 43-47

Mößeler A., Köttendorf S., Große Liesner V., Kamphues J. (2010) Impact of diets' physical form (particle size; meal/pelleted) on the milieu within the stomach content (dry matter content, $\mathrm{pH}$, chloride concentration) of pigs. Livestock Sci. 134, 146-148

Mößeler A., Wintermann M., Sander S. J., Kamphues J. (2012) Effect of grinding and pelleting fed either dry or liquid feed on dry matter and $\mathrm{pH}$ in the stomach of pigs and the development of gastric ulcers. J. Anim. Sci. 90, 343-345

Murray M. J. (1989) Endoscopic appearance of gastric lesions in foals: 94 cases (1987-1988). J. Am. Vet. Med. Assoc. 195, $1135-1141$ 
Murray M. J., Grodinsky C., Anderson C. W., Radue P. F., Schmidt G. R. (1989) Gastric ulcers in horses: a comparison of endoscopic findings in horses with and without clinical signs. Equine Vet. J. 21, 68-72

Murray M. J., Schusser G. F. (1993) Measurement of 24-h gastric $\mathrm{pH}$ using an indwelling $\mathrm{pH}$ electrode in horses unfed, fed and treated with ranitidine. Equine Vet. J. 25, 417-21

Murray M. J. (1994) Equine model of inducing ulceration in alimentary squamous epithelial mucosa. Digest. Dis. Sci. 39, 25302535

Murray M. J., Eichorn E. S. (1996) Effects of intermittent feed deprivation, intermittent feed deprivation with ranitidine administration, and stall confinement with ad libitum access to hay on gastric ulceration in horses. Am. J. Vet. Res. 57, 1599-1603

Murray M. J. (1999) Pathophysiology of peptic disorders in foals and horses: a review. Equine Vet. J. 31, 14-18

Murray M. J., Grady T. C. (2002) The effect of a pectin-lecithin complex on prevention of gastric mucosal lesions induced by feed deprivation in ponies. Equine Vet. J. 34, 195-198

Nadeau J. A., Andrews F. M., Mathew A. G., Argenzio R. A., Blakkford J. T., Sohtell M., Saxton A. M. (2000) Evaluation of diet as a cause of gastric ulcers in horses. Am. J. Vet. Res. 61, 784790

Nadeau J. A., Andrews F. M., Patton C. S., Argenzio R. A., Mathew A. G., Saxton A. M. (2003) Effects of hydrochloric acetic, butyric and proprionic acids on pathogenesis of ulcers in the nonglandular portion on the stomach of horses. Am. J. Vet. Res. 64, 404-412

Picavet M. T. (2002) Equine Gastric Ulcer Syndrome. Proc. 1st Equine Nutrition Health Congress Antwerpen, 1-12

Schusser G. F., May M., Damke C. (2006) Inflammatory and ulcerated gastric diseases. Pferdeheilkunde 22, 275-280

Vervuert I., Coenen M. (2002) Feeding and housing management in horses. Pferdeheilkunde 18, 629-632

Vervuert I., Coenen M. (2004) Nutritive Risiken für das Auftreten von Magengeschwüren beim Pferd. Pferdeheilkunde 20, 349-352

Vervuert I., Voigt K., Hollands T., Cuddeford D., Coenen M. (2009) The effect of mixing and changing the order of feeding oats and chopped alfalfa to horses on: glycaemic and insulinaemic responses, and breath hydrogen and methane production. J. Anim. Physiol. Anim. Nutr. 93, 631-638

Vondran S., Venner M., Vervuert I. Effects of two alfalfa preparations with different particle sizes (alfalfa chaff vs alfalfa pellets) on the gastric mucosa in weanlings. Equine Vet. J., under revision

Erweiterte Zusammenfassung

\section{Effekte verschiedener Raufutterzulagen auf die Magen-} schleimhaut nach dem Absetzen bei Warmblutfohlen

Das Vorkommen von Läsionen oder Ulzera in den verschiedenen Bereichen der Magenschleimhaut ist eine sowohl beim Sport- und Freizeitpferd als auch beim Fohlen seit vielen Jahren bekannte Erkrankung und daher Gegenstand zahlreicher Untersuchungen. In der aktuellen Nomenklatur wird aufgrund der unterschiedlichen Ulzerogenese zwischen dem EGGD (equine glandular gastric disease) und dem ESGD (equine squamous gastric disease) unterschieden. Die Kombination der klinischen Symptome wie Kolik, verlangsamte Futteraufnahme, knirschen mit den Zähnen, Abmagerung und gastroskopische Befunde kennzeichnen diese Erkrankung. Ursächlich kommen die Verabreichung von nichtsteroidalen Antiphlogistika, Stress infolge von überdurchschnittlicher Arbeit oder Transport, die Fütterung hoher Kraftfuttermengen, sowie lange Nahrungskarenzen in Frage. Im Allgemeinen erfolgt beim Pferd die Produktion der Salzsäure kontinuierlich ganz im Gegensatz zum Speichelfluss, welcher ausschließlich während der Futteraufnahme induziert wird. Folglich führt eine längere Nahrungskarenz zu einem Absinken des pH-Wertes mit Schädigung der verhornten Magenschleimhaut. Diese besitzt neben einer hohen Zellteilung, den äußerst dichten interzellulären "Tight-junctions" und der verhornten Oberfläche keine weiteren Schutzmechanismen. Im Gegensatz dazu ist die glanduläre Schleimhaut des Magens mit zahlreichen protektiven Barrieren ausgestattet. Hierzu zählt vor allem die Bicarbonat- und Schleimsekretion, welche die Pufferkapazität erhöhen und zu einem erhöhten $\mathrm{pH}-$ Wert im Bereich der Schleimhaut führen. Zahlreiche Arzneimittel wurden zur Prävention oder Therapie der Magenulzera beim Pferd entwickelt. Dabei ist das primäre Ziel, die Azidität im Magen zu reduzieren, sowie die empfindliche und wenig geschützte verhornte Magenschleimhaut intakt zu halten. Neben der medikamentellen Option wird generell empfohlen die Haltungsund Fütterungsbedingungen hinsichtlich einer ausreichenden Raufutteraufnahme (mindestens täglich $1,5 \mathrm{~kg}$ Trockensubstanz/100 kg KM) und reduzierter Stärkezufuhr (maximal $1 \mathrm{~g}$ Stärke/kg KM pro Mahlzeit) zu optimieren. Alternativ zu Heu erwies sich die Fütterung von Luzerneheu bei Sport- und Freizeitpferden als positiv in Bezug auf die Magenschleimhaut. Dabei wird vermutet, dass die hohen Calcium- und Proteingehalte der Luzerne als Puffersubstanz für die Magenschleimhaut gelten. In der vorliegenden Studie sollten die Auswirkungen der Fütterung von Luzernehäcksel auf die Magenschleimhaut bei Fohlen nach dem Absetzen von den Mutterstuten untersucht werden.

Es handelt sich um eine zweiteilige Blindstudie mit Kontrollgruppe, an insgesamt 89 Absetzern (41 weiblich, 48 männlich). Im ersten Teil der Studie wurden drei Gruppen mit jeweils 20 Fohlen untersucht (unmelassierte Luzernehäcksel; Heu; totale Mischfutterration (TMR)). Der zweite Teil der Studie erfolgte an zwei Gruppen (melassierte Luzernehäcksel; Heu) mit jeweils 19 Probanden. In beiden Abschnitten erfolgte die Fütterung der jeweiligen Ration unmittelbar nach dem Absetzen über 15-16 Tage. Die Absetzer jeder Gruppe wurden in Laufställen mit Paddocks auf Stroh gehalten. Die Fütterung von $\mathrm{Heu}$ und beider Luzernehäcksel- Formulierungen erfolgte zweimal täglich. Zusätzlich erhielten diese Gruppen dreimal täglich $2,7 \mathrm{~kg}$ Hafer pro Absetzer und ein vitaminisiertes Mineralfutter. Der TMR Gruppe wurde der Hafer und das vitaminierte Mineralfutter in entsprechenden Mengen eingemischt und mit der TMR zweimal täglich verabreicht. Eine Gastroskopie wurde sowohl direkt vor dem Absetzen als auch 15-16 Tage nach der Fütterung durchgeführt. In dieser Untersuchung wurden folgende acht Regionen nach der Bewertungsskala von Andrews et al. (1999) befundet: Saccus caecus, jeweils Pars glandularis und nonglandularis der Curvatura major und minor, das Antrum pyloricum, Pylorus und das Duodenum. Zusätzlich wurde an diesen Tagen auch die Körpermasse (KM) gemessen.

Im ersten und zweiten Studienabschnitt kam es zu keiner statistisch signifikanten Änderung der Körpermasse der Absetzer in Abhängigkeit der Fütterung. Im Mittel nahmen die Absetzer der TMR Gruppe um 2,8\% und die der Luzerne Gruppe um $1,1 \%$ an Gewicht zu. Die Heugruppe hingegen verzeichnete eine Körpergewichtsabnahme im Mittel um 1,3\%. Die mittlere Trockenmasseaufnahme lag mit 7,2 $\pm 0,02 \mathrm{~kg}$ pro Absetzer in der TMR Gruppe statistisch signifikant höher im Vergleich zu $5,0 \pm 0,03 \mathrm{~kg}$ in der Heugruppe und $4,87 \pm 1,0 \mathrm{~kg}$ in der Luzernehäckselgruppe. Die Prävalenz der Magenulzera im 
ersten Teil lag bereits vor dem Absetzen bei 44\%, und stieg nach dem Absetzen auf $93 \%$. Besonders die Pars nonglandularis der Curvatura minor zeigte bei der TMR- und Heugruppe nach dem Absetzen Läsionen der Magenschleimhaut. Der Pylorus wies in der Luzernehäckselgruppe bei signifikant mehr Fohlen Läsionen (Score Median: 0, 25/75\% Perzentil: 2/2) auf im Vergleich zur TMR- (Score Median: 0, 25/75\% Perzentil: 0/0) oder Heufütterung (Score Median: 0, 25/75\% Perzentil: $0 / 1$ ).

Im zweiten Studienabschnitt war eine mittlere Trockenmasseaufnahme pro Absetzer mit 5,2 kg $\pm 0,03 \mathrm{~kg}$ in der Heugruppe und mit 6,3 $\pm 1,17 \mathrm{~kg}$ in der melassierten Luzernehäckselgruppe zu beobachten. Es wurden bei $86 \%$ der Fohlen vor dem Absetzen Magenläsionen festgestellt. 15 Tage nach dem Absetzen zeigte sich ein Anstieg auf 97\%. Die Beurteilung des Pylorus ergab statistisch signifikant mehr Läsionen in der melassierten Luzernehäckselgruppe (Score Median: 1, 25/75\% Perzentil: 1/1) verglichen mit einer befundfreien Heugruppe.

Die in beiden Studienabschnitten ermittelten hohen Prävalenzen der Magenulzera bereits vor dem Absetzen decken sich nicht mit den Ergebnissen bisher veröffentlichter Studien. In der Literatur wird lediglich eine Prävalenz von 9\% (Murray 1989), 30\% (Murray 1999) und 41-55\% (Dahlkamp et al. 2012) angeben. Nach dem Absetzen war in der eigenen Studie besonders die Luzernhäckselgruppe auffällig. Bemerkenswert ist, dass zu keinem Zeitpunkt der Studie klinische Symptome wie Kolik, langsames Fressverhalten oder reduziertes Allgemeinbefinden bei den Probanden erkennbar waren. Im Gegensatz zu den in der Literatur erhobenen Befunden konnte in der eigenen Studie eine hohe Anzahl an Fohlen mit Magenbefunde im Bereich des Pylorus bei der Fütterung von luzernehäckseln festgestellt werden. Möglicherweise lässt sich dies durch die reduzierte Futteraufnahme besonders in der ersten Luzernehäckselgruppe in den ersten 3 Tagen nach dem Absetzen erklären. Durch eine reduzierte Futteraufnahme der Luzernehäcksel entsteht ein Missverhältnis in der Rau- und Kraftfutteraufnahme. Neben der intensiveren Kautätigkeit und damit gesteigerten Speichelproduktion während der Raufutteraufnahme entsteht ein flüssiger Futterbrei mit kurzer Verweildaver im Magen. Wenig eingespeichelte und damit trokkene Futterbestandteile verbleiben im Unterschied dazu länger im Magen und führen zu einer vermehrten Anregung der Salzsäureproduktion und zu bakteriellen Fermentationsprozessen. Die Futterakzeptanz der melassierten Luzernehäcksel in der zweiten Versuchsphase war mit täglich 6,3 $1,17 \mathrm{~kg}$ im Vergleich zu 5,2 kg $\pm 0,03 \mathrm{~kg}$ in der Heugruppe besser. Trotzdem ließen sich auch hier nach dem Absetzen mehr Befunde im Pylorusbereich feststellen. Eine Erklärung könnte die Partikelgröße der Luzernehäcksel liefern, wobei eine mechanische Reizung denkbar ist. Es bleibt in der vorliegenden Studie offen, ob eine mechanische Reizung der Pylorusschleimhaut auf die feinen oder langen, hartkantigen Futterpartikel zurükkzuführen ist. So besteht der dringende Bedarf an weiterführenden Untersuchungen über den Zusammenhang zwischen den verschiedenen Teilen der Luzerne (Blattmasse bzw. Stengelanteil) und der Magenschleimhaut von Fohlen und adulten Pferden.

Schlüsselwörter: EGUS / Fütterung / Luzerne-Häcksel / Absetzen / Fohlen 